\title{
Proctolin in Identified Serotonergic, Dopaminergic, and Cholinergic Neurons in the Lobster, Homarus americanus
}

\author{
Kathleen King Siwicki, ${ }^{a}$ Barbara S. Beltz, and Edward A. Kravitz \\ Department of Neurobiology, Harvard Medical School, Boston, Massachusetts 02115
}

In order to explore the functions of the peptide proctolin in the lobster nervous system, 3 classes of neurons showing proctolin-like immunocytochemical staining were selected for study. These neurons were identified on the basis of physiological and/or morphological criteria, isolated by dissections, and analyzed with biochemical methods to determine (1) whether they contained authentic proctolin and (2) which classical neurotransmitters coexisted with the peptide. Pairs of large proctolin-immunoreactive neurons in fifth thoracic and first abdominal ganglia were identified as serotonin-immunoreactive neurons (Beltz and Kravitz, 1983, 1987) by staining serial sections of the ganglia alternately with the 2 antisera. Physiologically identified cells, dissected from the ganglia and analyzed with high-performance liquid chromatography (HPLC), contained approximately 20 $\mu \mathrm{M}$ proctolin and $0.5 \mathrm{mM}$ serotonin. A large proctolin-immunoreactive neuron in the circumesophageal ganglion was identified as the lobster homolog of a dopaminergic neurosecretory cell found in other crustaceans (Cooke and Goldstone, 1970). The large lobster cell stained with antityrosine hydroxylase antiserum, and synthesized ${ }^{3} \mathrm{H}$-dopamine from ${ }^{3} \mathrm{H}$-tyrosine. Dissected cell bodies, analyzed by HPLC, contained approximately $25 \mu \mathrm{M}$ proctolin. Proctolinimmunoreactive sensory neurons were identified as large stained fibers that terminated in sensory dendrites of the oval organ mechanoreceptor in the scaphognathite (Pasztor, 1979; Pasztor and Bush, 1982). The largest sensory fiber was isolated for biochemical studies. It synthesized ${ }^{3} \mathrm{H}$ acetylcholine from ${ }^{3} \mathrm{H}$-choline and, by HPLC analysis, was found to contain approximately $3 \mu \mathrm{m}$ proctolin. Thus, proctolin coexists with different conventional transmitters in several classes of identified lobster neurons. Investigations of the actions of proctolin in these different contexts should contribute to a more complete understanding of the diverse functions of neuropeptides and their roles as cotransmitters.

During the past decade, it has become clear that neurons can contain more than one neuroactive substance. Immunocyto-

\footnotetext{
Received May 12, 1986; revised Aug. 5, 1986; accepted Aug. 8, 1986.

We wish to thank Dr. Valerie Pasztor for introducing us to the oval organ, and Drs. Michael O'Shea and Tong Joh for generous gifts of antisera. We also thank H. Mekeel, M. Lee, and J. Gagliardi for technical assistance, and D. Cox for secretarial support. This work was supported by NIH Grants NS-07848 to E.A.K. and MH-18012 to K.K.S

Correspondence should be addressed to Dr. Edward A. Kravitz at the above address.

a Present address: Biology Department, Brandeis University, Waltham, MA 02254.
}

Copyright (C) 1987 Society for Neuroscience $0270-6474 / 87 / 020522-11 \$ 02.00 / 0$ chemical demonstrations of the coexistence of peptides and conventional transmitters are numerous, but direct biochemical identification and quantitation of cellular constituents are less common, and physiological studies of the functional implications of colocalizations are even rarer. One particularly well studied example is the coexistence of acetylcholine, vasoactive intestinal polypeptide (VIP) and peptide $\mathrm{HI}$ in parasympathetic neurons innervating the rat submandibular gland. In this case, the peptides and the conventional transmitter act cooperatively to stimulate secretion and vasodilation (Lundberg, 1981; Lundbcrg and Hökfclt, 1983; Lundbcrg ct al., 1984). A straightforward interpretation of these studies was made possible by the relatively homogeneous population of parasympathetic neurons in this system. Many identified neurons in invertebrates possess the anatomical simplicity required for clear analyses of transmitter corelease and the functional interactions between cotransmitters. Immunocytochemical evidence exists for the colocalization of a cholecystokinin-like peptide with serotonin in molluscan metacerebral giant cells (Osborne et al., 1982), but the amino acid sequence of the immunoreactive peptide is not known. Also in mollusks, identified neurons in the buccal ganglion contain small cardioactive peptides, $\mathrm{SCP}_{\mathrm{a}}$ and $\mathrm{SCP}_{\mathrm{b}}$, together with ACh (Lloyd et al., 1981, 1985; Lloyd, 1982). FMRF amide-immunoreactive heart excitatory motoneurons in the leech are another example of identified, putatively cholinergic neurons that contain a neuropeptide (Kuhlman et al., 1985a, b). The peptide proctolin (Arg-Tyr-Leu-Pro-Thr) has been localized to several types of identified neurons in arthropods. These include the lateral white (LW) neurosecretory cells in abdominal ganglia of the cockroach, Periplaneta americana (O'Shea and Adams, 1981), and several examples of identified motoneurons. Proctolin-containing motoneurons have proven to be particularly useful models for studying the actions of the peptide. The slow coxal depressor motoneurons of the cockroach leg (O'Shea and Bishop, 1982; Adams and O'Shea, 1983), the slow extensor tibialis motoneuron (SETi) of the locust hindleg (Worden et al., 1985), and the tonic flexor motoneurons of the crayfish abdomen (Bishop et al., 1984a, b, 1985) all contain proctolin together with a conventional, fast-acting neuromuscular transmitter. The peptide modulates the physiology of each of these muscles in unique and interesting ways.

We have recently completed immunocytochemical studies of the cellular distribution of proctolin-like antigens in the lobster nervous system (Siwicki and Bishop, 1986). The results suggested that among the stained neurons, certain neurosecretory cells, sensory neurons, and motoneurons might be readily identifiable in one preparation after another. Furthermore, previous studies in lobsters and related crustaceans have suggested that the identifiable neurons might also contain conventional neu- 
rotransmitters, such as serotonin, dopamine, and $\mathrm{ACh}$. The results presented in this paper provide direct biochemical evidence for the coexistence of proctolin with (1) serotonin in pairs of identified neurosecretory cells in the fifth thoracic (T5) and first abdominal (A1) ganglia (Beltz and Kravitz, 1983, 1987); with (2) dopamine in the largest neuron of the circumesophageal (or commissural) ganglion (CG) (Cooke and Goldstone, 1970); and with (3) ACh in an identified sensory neuron of the oval organ mechanoreceptor in the scaphognathite (Pasztor, 1979; Pasztor and Bush, 1982).

\section{Materials and Methods}

\section{Immunocytochemical procedures}

Whole mounts of central ganglia from juvenile lobsters $(2-20 \mathrm{gm})$ were stained for proctolin-like immunoreactivity with rabbit anti-proctolin antiserum (No. 9 of Bishop et al., 1981) and the Vectastain biotinavidin-peroxidase method (Vector Laboratories), as described previously (Siwicki and Bishop, 1986). Circumesophageal ganglia were processed for tyrosine hydroxylase (TH)-like immunoreactivity with a similar procedure, using a 1:500 dilution of a rabbit anti-TH antiserum (kindly supplied by Dr. T. Joh). The immunogen was a proteolytic fragment of purified rat $\mathrm{TH}$, which included the active site of the enzyme (T. Joh, personal communication).

Ganglia to be sectioned were dissected from mature lobsters $(0.4-0.5$ $\mathrm{kg}) 2 \mathrm{~d}$ after colchicine solutions had been injected into the ventral hemolymph sinus $(15 \mathrm{mg} / \mathrm{kg})$. T5 and Al ganglia were fixed overnight at $4^{\circ} \mathrm{C}$ with $4 \%$ paraformaldehyde in PBS $(462 \mathrm{~mm} \mathrm{NaCl}, 16 \mathrm{~mm} \mathrm{KCl}$, $0.1 \mathrm{~m} \mathrm{Na}$ phosphate, $\mathrm{pH} 7.4$ ), rinsed with $0.1 \mathrm{M}$ phosphate buffer, $\mathrm{pH}$ $7.4(\mathrm{~PB})$, then infiltrated with $30 \%$ sucrose in PB. Serial frozen sections $(10 \mu \mathrm{m})$ were cut on a Bright cryostat. Alternate sections were stained with anti-serotonin and anti-proctolin antisera. Rabbit anti-proctolin antiserum (No. 9 of Bishop et al., 1981) was used at a dilution of 1:600, after being preabsorbed to reduce nonspecific staining, as described previously (Siwicki and Bishop, 1986). Rabbit anti-serotonin antiserum (Immunonuclear) was used at a dilution of 1:200. Sections stained for serotonin were processed in $\mathrm{PB}$, and those for proctolin in $\mathrm{PB}$ plus $0.9 \% \mathrm{NaCl}$. All incubations were carried out at room temperature. Sections were preincubated for 40 min with $10 \%$ normal goat serum in buffer solutions containing $0.3 \%$ Triton X-100. Serotonin sections were incubated for $1 \mathrm{hr}$, and proctolin sections for $4 \mathrm{hr}$, in their respective primary antibody solutions. The primary antibody solutions contained $0.3 \%$ Triton X-100; subsequent rinse and incubation buffers contained $0.03 \%$ Triton X-100. Sections were incubated with biotinylated goat anti-rabbit antiserum (diluted 1:250; Vector) for $1 \mathrm{hr}$, rinsed for $30 \mathrm{~min}$, then incubated with the avidin-biotin-peroxidase reagent (diluted 1:125) from a Vectastain kit (Vector) for $2 \mathrm{hr}$. Buffer solutions without Triton were used for the final rinses. Bound peroxidase was visualized by incubating sections with $3,3^{\prime}$-diaminobenzidine $(0.5 \mathrm{mg} /$ $\mathrm{ml}$ ) and $0.003 \% \mathrm{H}_{2} \mathrm{O}_{2}$. Sections were dehydrated with increasing concentrations of ethanol, cleared in xylene, and coverslips applied with Permount (Fisher).

\section{Biochemical analysis of identified $C G, T 5$ and $A 1$ neurons}

Cell identifications and dissections. Adult lobsters $(0.4-0.5 \mathrm{~kg})$ were treated with colchicine $2-3$ d prior to dissections, as described above. Ganglia were dissected under physiological saline $(462 \mathrm{~mm} \mathrm{NaCl}, 16$ $\mathrm{mM} \mathrm{KCl}, 26 \mathrm{~mm} \mathrm{CaCl}, 8 \mathrm{~mm} \mathrm{MgCl}_{2}, 11 \mathrm{~mm}$ glucose, $10 \mathrm{~mm}$ Trismaleate buffer, $\mathrm{pH} 7.4$ ), pinned in small Sylgard- (Dow Corning) coated petri dishes and desheathed. The largest cell in the CG was identified by its size and characteristic position at the anterior margin of the ganglion. The scrotonin-immunorcactive cclls in T5 and Al were identified physiologically, as described in the following paper (Beltz and Kravitz, 1987). Identified cells were injected with fast green, as were two unidentified control cells in each ganglion. Control cells of approximately the same size as the identified cells were selected from regions of the T5 and Al ganglia that did not contain proctolin-immunoreactive cell bodies (Siwicki and Bishop, 1986).

After the cells of interest had been identified, preparations were frozen $\left(-20^{\circ} \mathrm{C}\right)$ in $40 \%$ propylene glycol, $60 \%$ saline (Ono and McCaman, 1980). The dishes were surrounded with dry ice during the cell dissections. Each identified cell was plucked from the ganglion by slipping a loop of fine copper wire over the cell body, and tightening the loop around the neck of the axon. The cell body attached to the wire was transferred to a $10 \mu \mathrm{l}$ drop of $0.09 \%$ trifluoracetic acid, $10 \%$ methanol (TFA-MeOH) containing $10^{5} \mathrm{M}$ ascorbic acid and $10^{6} \mathrm{M}$ dihydroxybenzylamine (DHBA). Unidentified control cells were extracted in this same solution. Individual cell extracts were stored at $-20^{\circ} \mathrm{C}$, then pooled just before high-performance liquid chromatography (HPLC) analysis into groups of T5 5-HT cells, A1 5-HT cells, large CG cells, negative control celis, and positive control cells (extraction medium supplemented with $10^{-9} \mathrm{M}$ proctolin, $10^{-7} \mathrm{M}$ serotonin, and $10^{-7} \mathrm{M}$ dopamine)

Incubations with ${ }^{3} \mathrm{H}$-tyrosine. Nerve cords from the $\mathrm{CG}$ through $\mathrm{A} 2$ were pinned in narrow troughs in Sylgard-coated petri dishes and bathed in $3 \mathrm{ml}$ of saline containing $50 \mu \mathrm{Ci} / \mathrm{ml} \mathrm{L}-2,6-{ }^{3} \mathrm{H}$-tyrosine (specific activity, $41.5 \mathrm{Ci} / \mathrm{mmol}$; final concentration $1.2 \times 10^{-6} \mathrm{M}$ ). After incubating for $17 \mathrm{hr}$ at $12^{\circ} \mathrm{C}$, the preparations were rinsed with fresh saline, and the $\mathrm{CG}, \mathrm{T} 5$, and $\mathrm{A} 1$ cells were identified and dissected as described above. Each cell body was extracted in $50 \mu \mathrm{l}$ of TFA-MeOH containing $10^{5} \mathrm{M}$ ascorbic acid, $10^{6} \mathrm{M}$ DHBA, $10^{6} \mathrm{M}$ dopamine, and $10^{6} \mathrm{M}$ serotonin, and stored at $-20^{\circ} \mathrm{C}$.

Proctolin HPLC analysis. The HPLC system consisted of 2 Waters pumps (Models 6000A and M-45) controlled by a Waters Model 660 solvent flow programmer. For peptide separations, samples were applied through an Altex 210 injection valve to a reverse-phase column (Waters $\mu$ Bondapak C18). The column effluent passed through a Waters Model $441 \mathrm{UV}$ absorbance monitor that measured absorbance at $214 \mathrm{~nm}$ to an ISCO Model 1850 fraction collector. The column was equilibrated with TFA-MeOH at a flow rate of $0.5 \mathrm{ml} / \mathrm{min}$. Samples were injected in 50-250 $\mu \mathrm{l}$ volumes of this solvent, and eluted with a gradient of 10 to $20 \%$ methanol. One minute column fractions $(0.5 \mathrm{ml})$ were collected and stored at $-20^{\circ} \mathrm{C}$. Aliquots of the fractions were lyophilized and resuspended in buffer for proctolin radioimmunoassay (RIA) (Schwarz et al., 1984).

Combined proctolin-amine HPLC analysis. To analyze samples for both proctolin and amines, 2 sequential column separations were performed. First, samples were applied to the C-18 column with the TFA$\mathrm{MeOH}$ solvent system described above. In order to avoid UV inactivation of serotonin, the column effluent did not pass through the UV absorbance monitor, but was collected directly in the fraction collector. Since even the fluorescent lights in the laboratory decreased the recovery of serotonin, column fractions were collected in the dark. Amines eluted in the void volume fractions, while proctolin was retained by the column and eluted with increasing methanol concentrations. The void volume fractions were pooled, frozen in liquid $\mathrm{N}_{2}$, and lyophilized. All other fractions were stored at $-20^{\circ} \mathrm{C}$ and later assayed for proctolin-like immunoreactivity (PLI) by RIA.

The lyophilized void volume fractions were resuspended in $250 \mu 1$ of a solvent used in a second HPLC system that was optimized for the separation and detection of amines. An Altex reverse-phase column was equilibrated at a flow rate of $0.5 \mathrm{ml} / \mathrm{min}$ with a solution containing 20 mM sodium phosphate, pH 3.0, $0.1 \mathrm{~mm}$ EDTA, $10 \%$ methanol, and $0.01 \%$ sodium octyl sulfate. An electrochemical detector (Bioanalytical) monitored the elution of oxidizable substances, and the output of the detector was recorded with a Perkin-Elmer chart recorder. The electrode potential was set at $0.5 \mathrm{~V}$. In a few experiments where tissues had been preincubated with ${ }^{3} \mathrm{H}$-tyrosine, the tubing that usually directed the column effluent to the electrochemical detector was connected instead to the fraction collector, and the elution of radioactivity was monitored by liquid scintillation counting.

\section{Biochemical analysis of oval organ axons}

Dissections. Large adult lobsters $(\sim 1 \mathrm{~kg})$ were used for these experiments. The bilaterally paired oval organs were dissected from the base of the scaphognathite, still attached via the second maxilla nerve to the subesophageal ganglion (SG). After severing other nerve roots and connectives, the SG, with the 2 attached oval organs, was removed from the animal and pinned in a small Sylgard-coated petri dish. Other branches of the second maxilla nerve were peeled away, leaving the small bundle of fibers that entered the oval organ intact. Cross sections of this branch of the nerve (see Fig. $5 b$ ) showed that it contains 5 large axons and many small ones. The bundles of small axons were pulled away carefully, and the 5 large axons were teased apart for most of their $2 \mathrm{~cm}$ lengths. The largest axon (ca. $30 \mu \mathrm{m}$ in diameter) was consistently isolated from all other axons in the nerve (Fig. 5c). The other 4 large axons (15-25 $\mu \mathrm{m}$ in diameter) sometimes ran as tightly associated pairs that could not be separated into single axons without undue damage. 
Incubations with ${ }^{3} \mathrm{H}$-choline. The dissected axons, attached proximally to the SG and distally to the oval organ, were incubated overnight at $12^{\circ} \mathrm{C}$ in saline containing $100 \mu \mathrm{Ci} / \mathrm{ml}^{3} \mathrm{H}$-choline (specific activity, $80 \mathrm{Ci} / \mathrm{mm}$ l; final concentration, $1 \times 10^{-6} \mathrm{M}$ ). At the end of the incubations, tissues were rinsed several times with fresh saline, and the individual axons and axon pairs were transferred to $20 \mu \mathrm{l}$ of an acidextraction medium containing choline and ACh (20 $\mathrm{mg} / \mathrm{ml}$ of each). In some experiments, axons were extracted in electrophoresis buffer $(2 \%$ formic acid, $8 \%$ acetic acid, pH 1.9); in other cases, TFA-MeOH was used. After several cycles of freezing and thawing, the axon extracts were stored at $-20^{\circ} \mathrm{C}$ until analyzed by either high-voltage paper electrophoresis or HPLC.

High-voltage paper electrophoresis. The procedure developed by Hildebrand et al. (1971) was used to separate ${ }^{3} \mathrm{H}$-choline and ${ }^{3} \mathrm{H}-\mathrm{ACh}$. Samples were applied in $5 \mu \mathrm{l}$ aliquots at the anode end of long sheets $(110 \times 45 \mathrm{~cm})$ of Whatman chromatography paper. The paper was saturated with electrophoresis buffer, carefully blotted, and subjected to high voltage ( $6000 \mathrm{~V}$ ) for $1.5-2 \mathrm{hr}$. The paper was dried and exposed to iodine vapors for $1-2 \mathrm{hr}$ in order to visualize the choline and $\mathrm{ACh}$ standards. Each lane was cut into $1 \mathrm{~cm}$ fractions, which were extracted in $0.4 \mathrm{ml} 0.1 \mathrm{M} \mathrm{HCl}$ for $1-2 \mathrm{hr}$, then suspended in $4 \mathrm{ml}$ of aqueous counting scintillant (Amersham). Radioactivity was measured in a Packard TriCarb liquid scintillation counter. The averaged cpm from multiple 10 min counts of each fraction were used to construct electrophoretic profiles of the radioactivity in each sample.

Acetylcholinesterase treatment. To confirm that the peaks of radioactivity comigrating with $\mathrm{ACh}$ were actually ${ }^{3} \mathrm{H}-\mathrm{ACh}$, several tissue extracts were treated with specific AChE (from electric eel; Sigma Type V-S) prior to electrophoresis. Paired aliquots of samples were dried under a stream of $\mathrm{N}_{2}$ and resuspended in $10 \mu \mathrm{l} 0.5 \mathrm{M} \mathrm{K}$ phosphate, $\mathrm{pH}$ 8.0. Another $5 \mu \mathrm{l}$ of buffer, containing either 0 or 1 unit of $\mathrm{AChE}$, was added to each. After $30 \mathrm{~min}$ at room temperature, the reaction was stopped by adding $10 \mu \mathrm{l}$ electrophoresis buffer containing $10 \mathrm{mg} / \mathrm{ml}$ $\mathrm{ACh}$. The treated samples and untreated controls were spotted on chromatography paper and subjected to electrophoresis.

\section{Results}

\section{Proctolin-serotonin cells in $T 5$ and $A 1$}

Pairs of large, proctolin-immunoreactive neurons in the fifth thoracic (Fig. 1a) and first abdominal (Fig. 1d) ganglia are similar in size and position to pairs of identified serotonin-immunoreactive neurosecretory cells in these ganglia (Beltz and Kravitz, 1983, 1987). To examine the possibility that the identified serotonin-immunoreactive neurons also might contain proctolin, alternate $10 \mu \mathrm{m}$ sections of the ganglia were stained with either anti-proctolin or anti-serotonin antiserum. Figure 1 shows that in both the T5 (Fig. 1,b,c) and A1 (Fig. 1,e,f) ganglia, identical cell pairs were stained in adjacent sections with the 2 different antisera, confirming that the identified neurosecretory cells contain both serotonin-like and proctolin-like immunoreactivities.

To determine whether the immunoreactive staining represented authentic serotonin and proctolin, cell bodies that had been identified physiologically were dissected from the ganglia and analyzed first for proctolin and then for monoamines with 2 sequential HPLC analyses (see Materials and Methods for details). PLI in fractions from the first column was quantitated by RIA (Fig. $2 a$ ); the elution of amines from the second column was monitored by electrochemical detection (Fig. $2 b$ ). Figure 2 illustrates the results of this type of analysis for: proctolin and amine standards $(a 1, b 1)$; and the pooled extracts of 19 identified T5 cells $(a 2, b 2), 21$ identified A1 cells $(a 3, b 3)$, and 26 unidentified control cells $(a 4, b 4$; see below for panels $a 5, b 5)$. The histograms in Figure $2 a$ show that the PLI detected in the T5 cells (a2) and the A1 cells (a3) eluted in the same fractions as authentic proctolin $(a 1)$. None of the fractions from the extract of control cells $(a 4)$ contained significant levels of PLI. The results of the amine analyses (Fig. $2 b$ ) indicate that the identified
T5 $(b 2)$ and A1 (b3) cells both contained peaks of serotonin (5-HT), while control cells did not (b4). Small peaks coeluting with dopamine (DA) were detected in all cell extracts (see below).

Combined with the anatomical and physiological studies of Beltz and Kravitz (1983, 1987), these immunocytochemical and HPLC analyses establish that pairs of identified neurosecretory cells in the T5 and A1 ganglia contain both proctolin and scrotonin. Assuming that the cell bodies were spheres with an average diameter of $100 \mu \mathrm{m}$, the concentration of proctolin in the cell bodies was $20-30 \mu \mathrm{M}$, and the concentration of serotonin was 0.4-0.6 mM. Similar serotonin concentrations have been reported in identified serotonergic neurons in mollusks (Osborne, 1977; Ono and McCaman, 1984).

\section{Proctolin-dopamine cells in the $C G$}

The largest cell body in each of the paired CG stained intensely with the anti-proctolin antiserum (Fig. $3 a$ ), and its immuoreactive axon (arrows in Fig. $3 a$ ) could be traced into the circumesophageal connective and anteriorly to the brain. In 2 very clearly stained preparations, the axon was observed to abruptly reverse direction at the posterior margin of the brain and return through the connective to the subesophageal ganglion (Siwicki and Bishop, 1986). This axonal trajectory was identical to that of the largest neuron of the crab CG, as visualized with catecholamine fluorescence by Cooke and Goldstone (1970). Biochemical studies of a homologous neuron (the $L$ cell) in the spiny lobster, Panulirus interruptus, demonstrated that it contained and synthesized DA (Barker et al., 1979; Kushner and Barker, 1983).

Immunocytochemical and biochemical methods were used to determine whether the large proctolin-immunoreactive neuron of the lobster CG was dopaminergic. Ganglia were stained with an antiserum against $\mathrm{TH}$, the enzyme that catalyzes the first step in the conversion of tyrosine to DA (Fig. $3 b$ ). When compared to another CG stained with the anti-proctolin antiserum (Fig. $3 a$ ), it was clear that a very similar large cell body with a characteristic axonal projection (arrows in Fig. 3) was stained with both antisera. This provided immunocytochemical evidence that this neuron contained or could synthesize both DA and proctolin.

Since this large cell body is readily identifiable in an unstained, desheathed $\mathrm{CG}$, it was possible to dissect numbers of these cells and subject them to HPLC analysis for proctolin and monoamines (Fig. 2, a5, b5). The pooled extracts of 14 large CG cells contained PLI (Fig. 2, a5) that eluted from the first column in the same fractions as authentic proctolin (a1). Calculations indicated an average cell body concentration of $25 \mu \mathrm{M}$ proctolin. The results of the amine analysis showed a small peak in the extract of the CG cells (Fig. 2, b5) with the same retention time as DA $(b 1)$. The presence of similar peaks in the extracts of both control cells $(b 4)$ and the T5 and A1 serotonin-proctolin cells (b, 2 and 3), however, raises doubts about whether this material is truly DA. There is no evidence that the T5 and A1 serotoninproctolin cells can synthesize DA: They did not stain with anti$\mathrm{TH}$ antiserum, nor did they convert ${ }^{3} \mathrm{H}$-tyrosine to ${ }^{3} \mathrm{H}$-DA (see below). Thus, the appearance of an oxidizable peak coeluting with DA is not sufficient evidence to conclude that a neuron is dopaminergic. An alternative interpretation is that all lobster neurons contain an oxidizable substance with the same retention time as DA in this HPLC system. Attempts to identify such a substance by applying standard solutions of known oxidizable 
The Journal of Neuroscience, February 1987, 7(2) 525
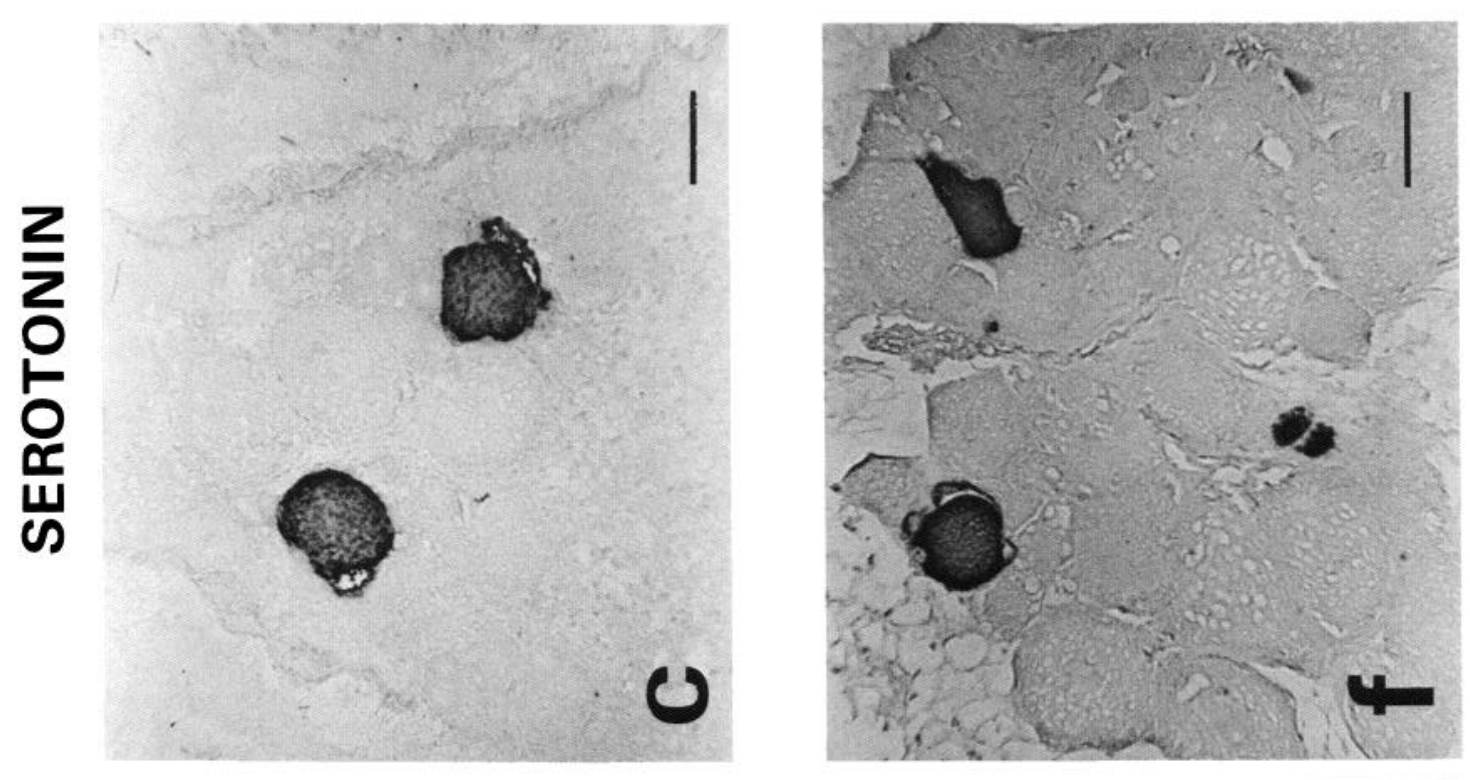

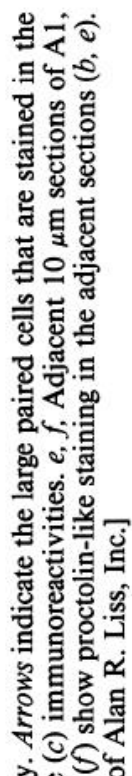
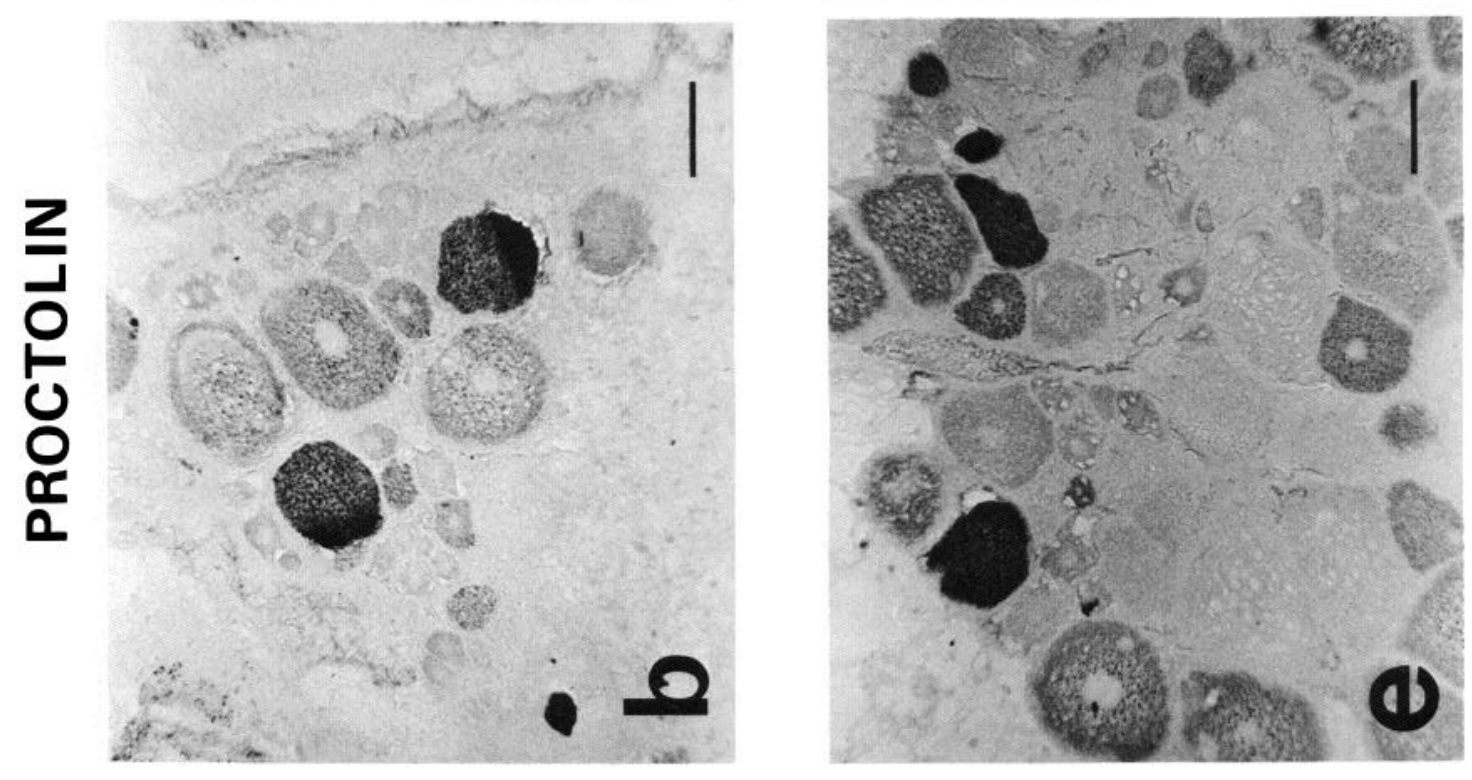

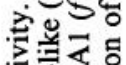

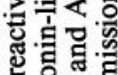

응

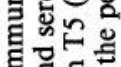

然 응 i. 응 흥 형 은운 훈 矛语 $\square$

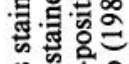
品造 究 응 蛅品

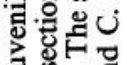
告 目

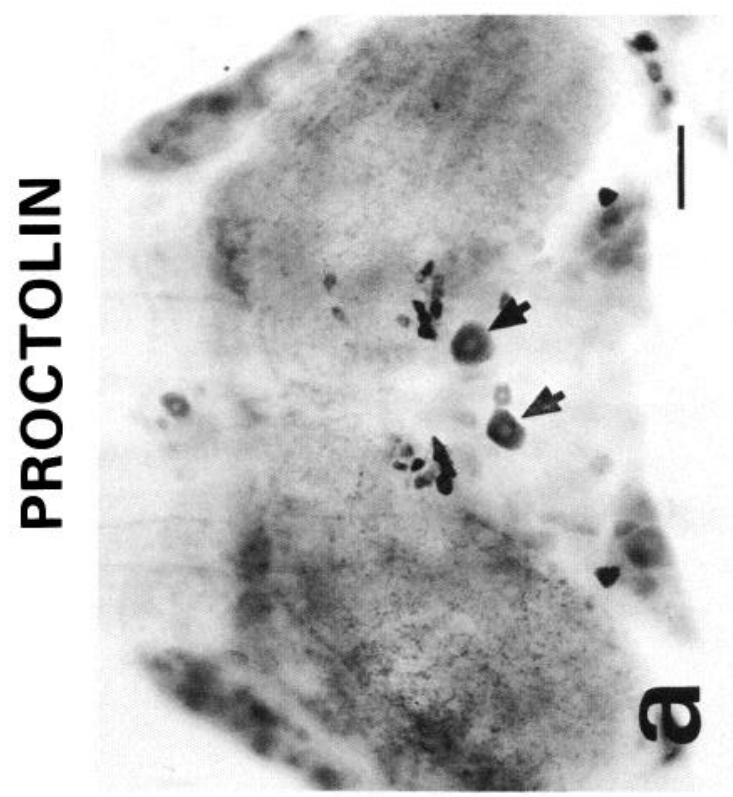
으를

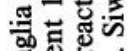
동

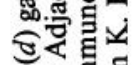
<i. \$s

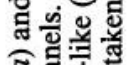
उิ 琼

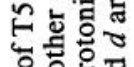

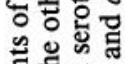

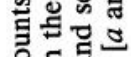
여옘 워

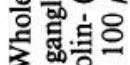


Figure 2. HPLC analyses for proctolin $(a 1-a 5)$ and monoamines $(b 1-b 5)$ : $a 1, b 1$, Standard solution $(200 \mu \mathrm{l})$ containing $1.3 \times 10^{-9} \mathrm{M}$ proctolin (proct), $2.5 \times 10^{-9} \mathrm{M}$ dopamine $(D A)$ and 2.5 $\times 10^{-5} \mathrm{M}$ serotonin (5-HT). Pooled extracts of: $a 2, b 2$, identified $T 5$ cells (19); $a 3, b 3$, identified $A 1$ cells (21); $a 4, b 4$, unidentified control cells (26); and $a 5$, $b 5$, identified $C G$ cells (14). $a$, When applied to a reverse-phase column equilibrated with TFA-MeOH and eluted with a gradient of $10-20 \%$ methanol, PLI in T5 (a2), Al (a3), and CG (a5) cells eluted in the same column fractions as authentic proctolin $(a 1)$. The void volume fractions were applied to a second HPLC system, optimized for separation and detection of monoamines $(b 1-b 5)$ (see Materials and Methods). In the amine analyses, the T5 (b2) and A1 (b3) cells contained small peaks of serotonin $(5-H T)$, while the control cells $(b 4)$ and CG cells $(b 5)$ did not. Small peaks comigrating with dopamine $(D A)$ were detected in all cell extracts (see text). Amounts of proctolin and amines in the cell extracts were calculated on the basis of averaged recoveries in 3 sets of standards (e.g., al, b1).
Standards

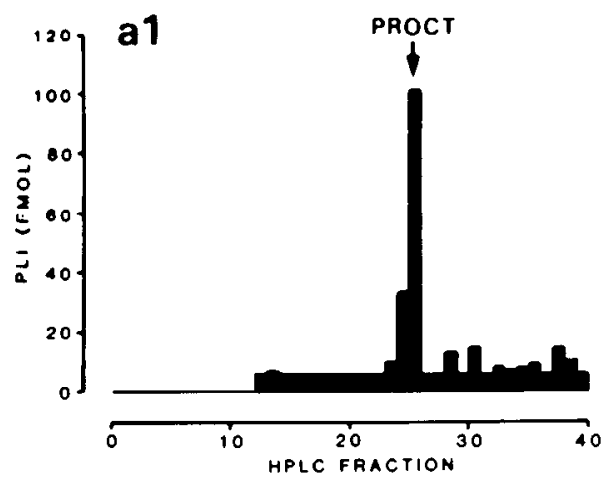

T5 cells

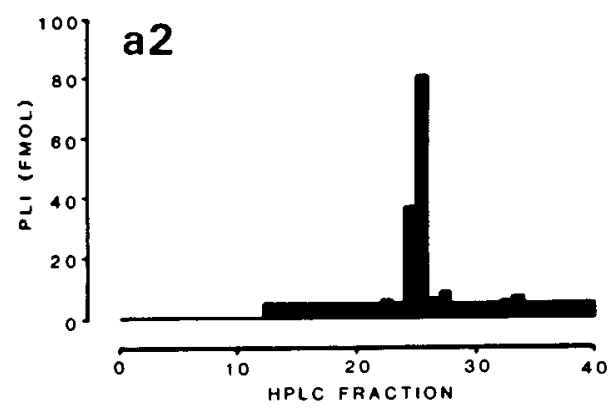

A1 cells
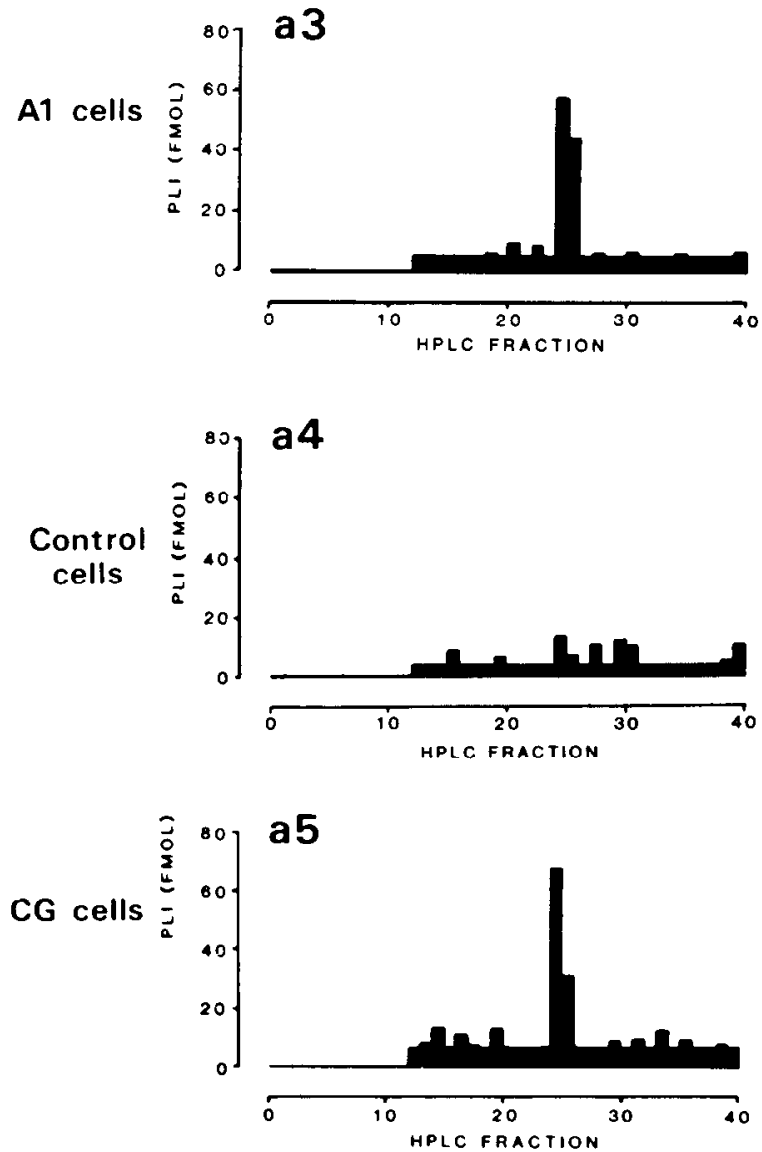
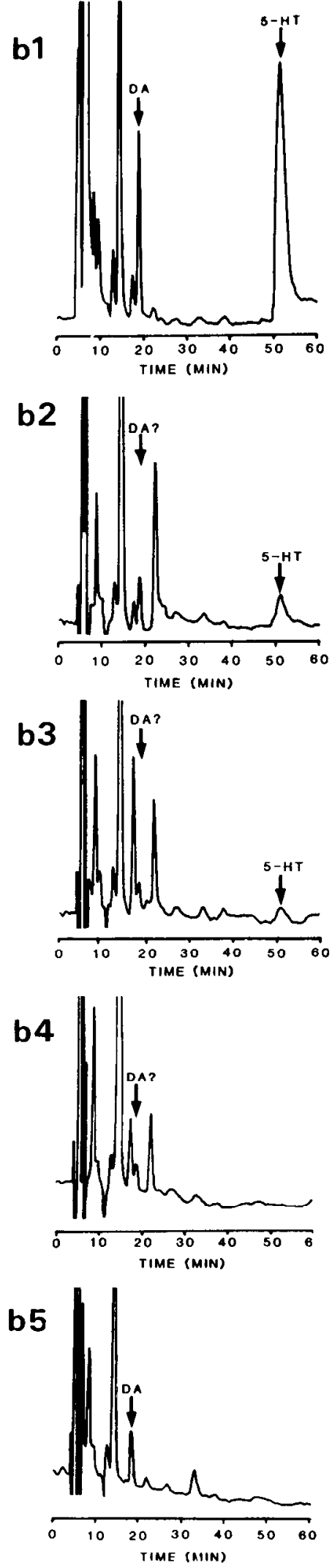

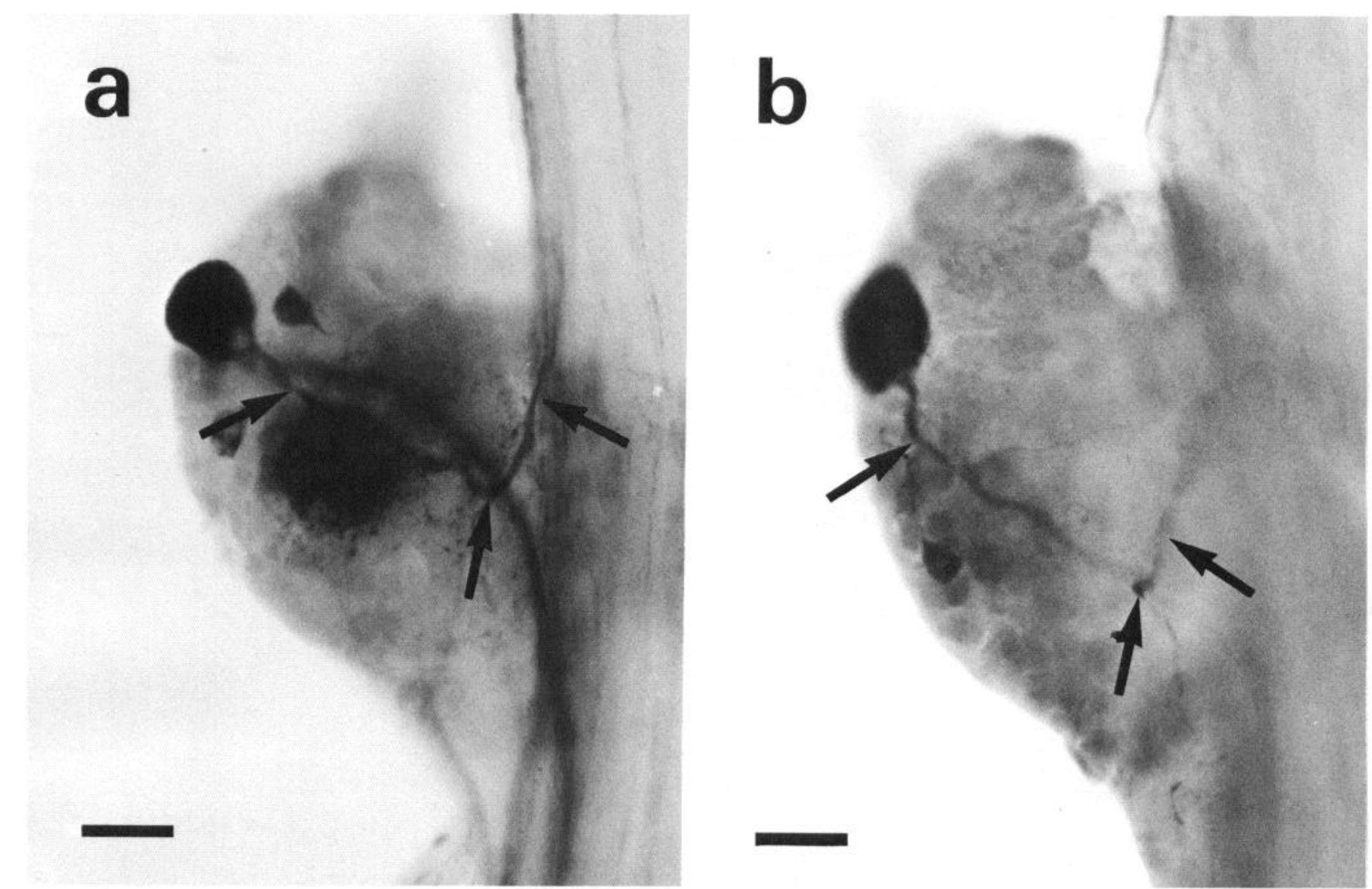

Figure 3. Whole mounts of circumesophageal ganglia stained for proctolin- (a) and tyrosine hydroxylase (TH)-like (b) immunoreactivities. The largest cell body in the ganglion was stained with both antisera. Its axon (arrows) can be traced into the ganglion, where it turns and continues anteriorly in the circumesophageal connective. Calibration bars, $50 \mu \mathrm{m}$. [From K. K. Siwicki et al. (1985) and reprinted with the permission of Peptides.]

metabolites to the column (e.g., octopamine, dihydroxyphenylalanine, norepinephrine, epinephrine, normetanephrine, 5 -hydroxytryptophan, and $N$-acetylserotonin) failed to reveal any that coeluted with DA.

A more stringent criterion for the transmitter identity of a neuron is its ability to synthesize a specific transmitter from a common precursor. The ability of the large CG neuron and the identified cell pairs in T5 and A1 to synthesize ${ }^{3} \mathrm{H}-\mathrm{DA}$ from ${ }^{3} \mathrm{H}$-tyrosine was tested by incubating desheathed ganglia overnight in saline containing $1.2 \mu \mathrm{M}{ }^{3} \mathrm{H}$-tyrosine. At the end of the incubation, the cells were dissected from the ganglia for HPLC analysis. For all 3 identified cell types, all radioactivity eluted from the first column in the void volume; none was detected in the proctolin fractions (data not shown). The results of the amine analysis are shown in Figure 4. The electrochemical detector (Fig. 4a) monitored the elution of cold standards (ascorbic acid, DHBA, DA, and serotonin). Histograms show the elution of radioactivity in extracts of a single large CG cell (Fig. $4 b$ ), 3 serotonin-proctolin cells from T5 (Fig. 4c), and 3 serotoninproctolin cells from Al (Fig. 4d). All 3 cell types contained a peak of radioactivity at $14 \mathrm{~min}$, the retention time of ${ }^{3} \mathrm{H}$-tyrosine. Only the large CG cell (Fig. $4 b$ ) contained ${ }^{3} \mathrm{H}-\mathrm{DA}$, as evidenced by the peak of radioactivity coincident with the cold DA standard at 19 min (Fig. $4 a$ ).

Therefore, it appears that proctolin and DA are colocalized in the large CG neuron, since it stained with both anti-proctolin and anti-TH antisera, contained PLI that comigrated with au- thentic proctolin in HPLC analysis, and synthesized ${ }^{3} \mathrm{H}-\mathrm{DA}$ from ${ }^{3} \mathrm{H}$-tyrosine.

\section{Proctolin and ACh in sensory neurons}

Proctolin-immunoreactive sensory neurons in the second maxilla nerve of the SG were identified by tracing stained fibers (Fig. $5 a$ ) from the ganglion to their peripheral arborizations in the oval organ, an elaborately branched array of neuronal processes near the base of the scaphognathite (the gill bailer). The finely branching processes of the oval organ arise from 3 large-diameter fibers $(15-30 \mu \mathrm{m})$ in the second maxilla nerve, and their cell bodies lie in the ganglion (Pasztor, 1979). Intracellular recordings from these fibers showed that they responded to mechanical stretch of the oval organ with both overshooting action potentials and graded depolarizations, suggesting a mechanoreceptive function for these neurons (Pasztor and Bush, 1982). When oval organs were stained with anti-proctolin antiserum, the distribution of immunoreactivity appeared strikingly similar to the pattern of dendritic staining observed by filling the nerve to the oval organ with $\mathrm{CoCl}_{2}$ (Siwicki et al., 1985; V. M. Pasztor, personal communication). Close examination of immunocytochemical preparations revealed that only 2 of the 3 sensory fibers to the oval organ were proctolin-immunoreactive (asterisks in Fig. $5 a$ ). The larger of the 2 stained fibers (upper right in Fig. $5 a$ ) is identifiable as the largest axon in the nerve. Histological cross sections of the nerve (Fig. $5 b$ ) show 5 large-diameter axons: the 3 large sensory fibers that arborize in the oval organ, and 2 
large motor axons that continue past the oval organ to a small depressor muscle. In addition, many small fibers are seen. Physiological studies (Pasztor and Bush, 1982) have indicated that the largest axon in the bundle (arrow in Fig. $5 b$ ) is one of the sensory fibers. The other 2 sensory fibers are similar in diameter to the 2 motor axons.

Since many crustacean sensory neurons are cholinergic (Barker et al., 1972), we examined the ability of the oval organ sensory fibers to synthesize ACh. The bundles of small axons in the nerve were dissected away and the 5 large axons were gently teased apart. The largest axon was most easily isolated, while the other 4 were usually left as 2 pairs. In 1 experiment, a dissected preparation was fixed, and cross sections of the largest axon confirmed that it was free of contaminating smaller axons, although variable amounts of connective tissue remained (Fig. 5c).

Axons were incubated overnight in saline containing $1 \mu \mathrm{M}$ ${ }^{3} \mathrm{H}$-choline, and the conversion of ${ }^{3} \mathrm{H}$-choline to ${ }^{3} \mathrm{H}$ - $\mathrm{ACh}$ by individual axons and axon pairs was determined by high-voltage paper electrophoresis (Hildebrand et al., 1971). In the experiment shown in Figure $6 A$, the largest axon and 1 of the 2 axon pairs contained peaks of radioactivity comigrating with the $\mathrm{ACh}$ standard, while the other axon pair did not. This result is consistent with the interpretation that the former are oval organ sensory axons and the latter are motor axons to the depressor muscle. In 20 preparations in which the largest axon was dissected cleanly, a peak of radioactivity was found comigrating with ACh; AChE treatment consistently eliminated the peak coincident with $\mathrm{ACh}$ and resulted in a larger peak comigrating with choline, as compared to an untreated aliquot of the same axon extract (Fig. 6B).

Preliminary RIAs of the large sensory axon indicated that it contained levels of proctolin-like immunoreactivity that were close to the limits of sensitivity of the assay (10-20 fmol). Therefore, extracts of several of the single large axons were pooled for HPLC analysis, but only after ${ }^{3} \mathrm{H}$-ACh synthesis had been confirmed for each axon used. Half of each axon extract was initially analyzed for ${ }^{3} \mathrm{H}-\mathrm{ACh}$ synthesis and hydrolysis by AChE (e.g., Fig. 6B), and then the remaining halves of the extracts were pooled and applied to a reverse-phase HPLC column. PLI from the pooled axon extracts eluted in the same fractions as authentic proctolin (Siwicki et al., 1985). In 2 experiments, the axons contained an average of $28 \mathrm{fmol}$ proctolin each, representing a concentration of approximately $3 \mu \mathrm{M}$.

These results indicate that the largest sensory fiber of the oval organ is likely to be cholinergic, since it can take up exogenous ${ }^{3} \mathrm{H}$-choline and convert it to ${ }^{3} \mathrm{H}$-ACh. Furthermore, by immunological and HPLC analyses, this same sensory neuron contained the peptide proctolin.

\section{Discussion}

The results presented in this paper show that several classes of identified lobster neurons contain a peptide that is antigenically and chromatographically indistinguishable from synthetic proctolin. These 2 criteria alone, however, are not sufficient to unambiguously establish that this substance is authentic proctolin. Among the other lines of evidence that support this conclusion is the following: Lobster pericardial organs, the neurosecretory tissues to which the identified T5, A1, and CG cells project, contain authentic proctolin. This was demonstrated by highresolution, fast-atom bombardment mass spectrometry of the a
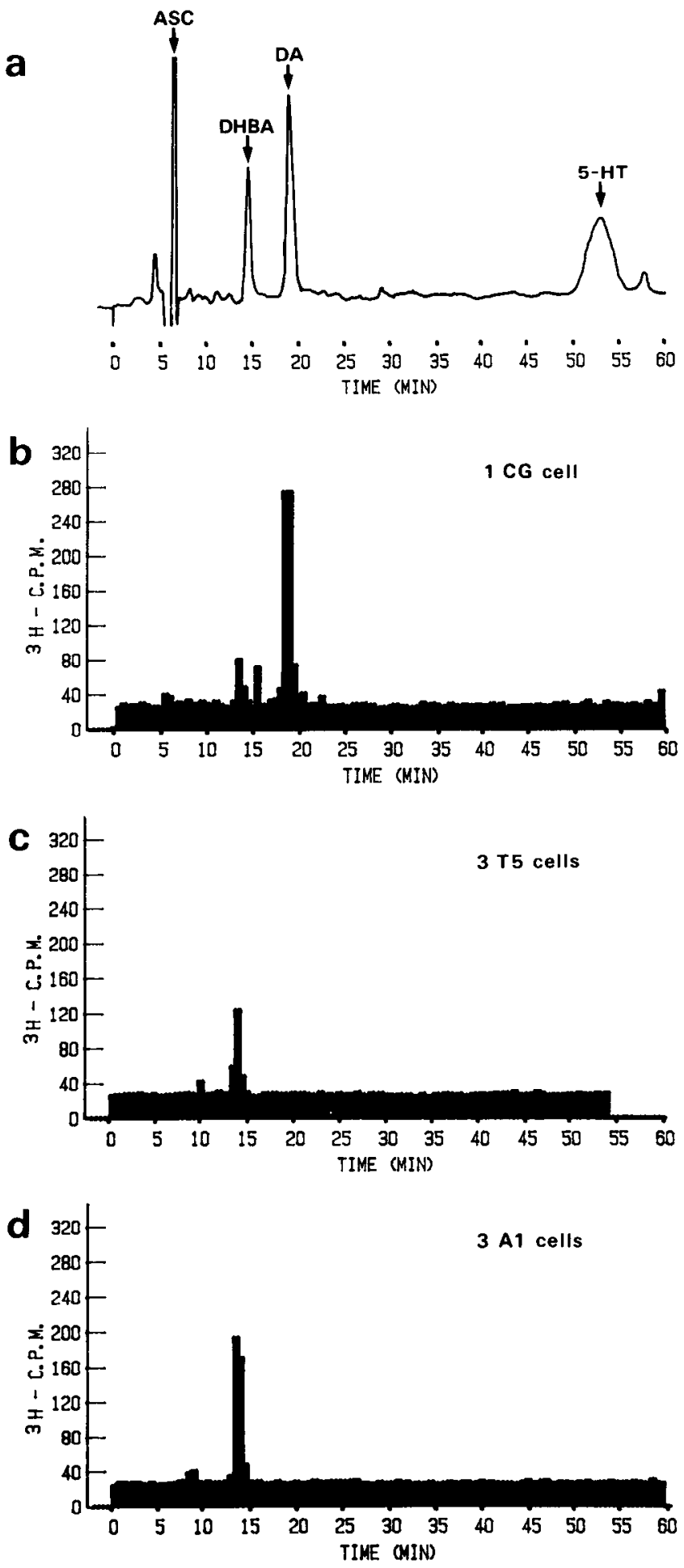

Figure 4. HPLC analyses for monoamines in cells dissected from ganglia after overnight incubations with ${ }^{3} \mathrm{H}$-tyrosine. $a$, Elution of cold standards that were added to dissected cells and monitored with an electrochemical detector. Peaks represent ascorbic acid $(A S C)$, dihydroxybenzylamine $(D H B A)$, dopamine $(D A)$, and serotonin $(5-H T) .{ }^{3} \mathrm{H}$ Tyrosine eluted at 14 min (nol shown). $b, c, d$, Elution of radioactivity in the extracts of dissected cells. The extracts contained $(b)$ a single large $C G$ cell, (c) 3 serotonin-proctolin cells from $T 5$, and (d) 3 serotoninproctolin cells from $A 1$. All cell extracts contained radioactivity that eluted at $14 \mathrm{~min}$, the retention time of ${ }^{3} \mathrm{H}$-tyrosine, but only the large $C G$ cell $(b)$ contained a peak of radioactivity coincident with $D A$. 

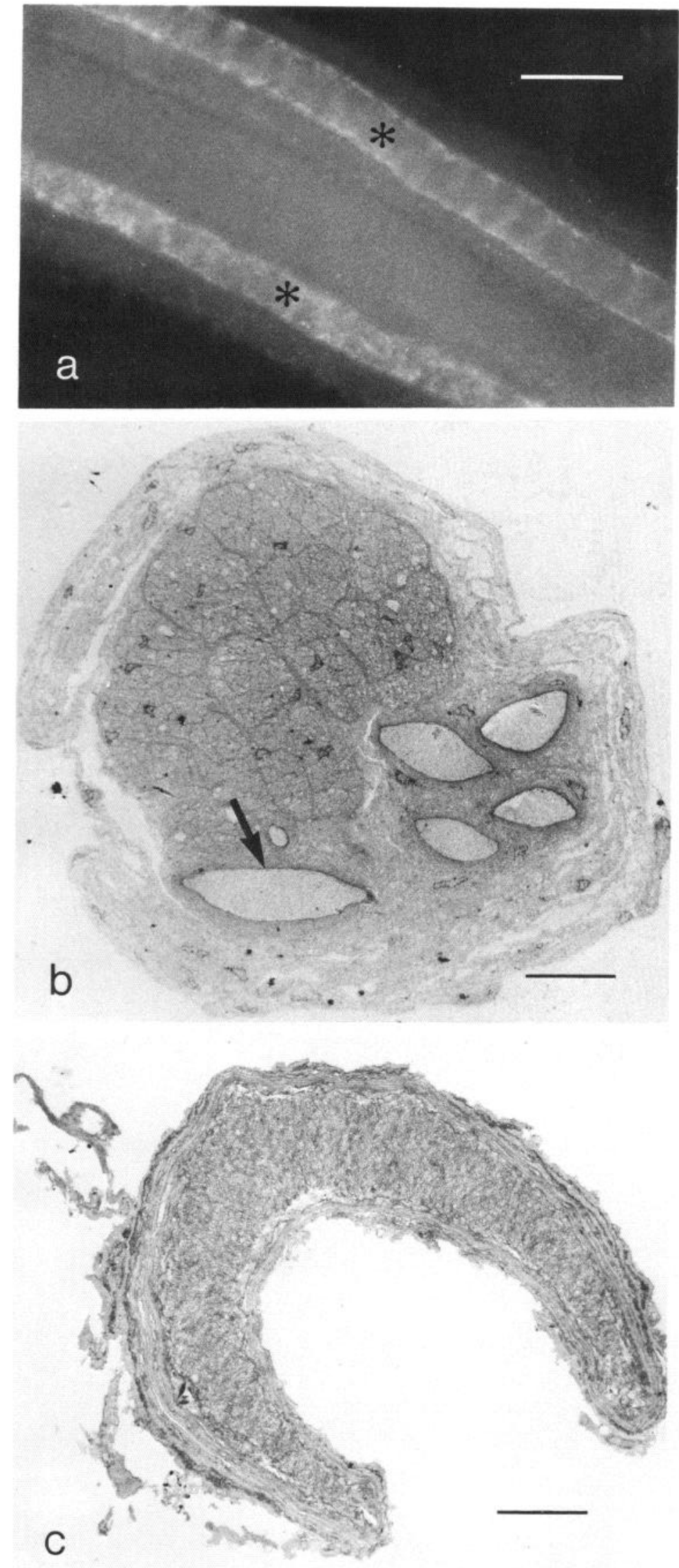

Figure 5. a, In whole mount immunocytochemical preparations of the second maxilla nerve, proctolin-like staining was apparent in 2 large-diameter fibers (asterisks). These immunoreactive fibers were traced into the oval organ, where they arborized extensively (see Siwicki et al., 1985). Calibration bar, $50 \mu \mathrm{m}$. $b$, Cross section of the branch of the second maxilla nerve that carries the oval organ sensory fibers. The nerve contains 5 large axons and numerous bundles of small fibers. The largest axon (arrow) was routinely dissected for biochemical analyses. Other large axons were dissected in pairs and analyzed in some experiments. Calibration bar, $40 \mu \mathrm{m}$. $c$, Cross section of the largest axon after being isolated from other axons in the nerve. Some connective tissue can be seen clinging to the ensheathed axon. Calibration bar, $3 \mu \mathrm{m}$. 

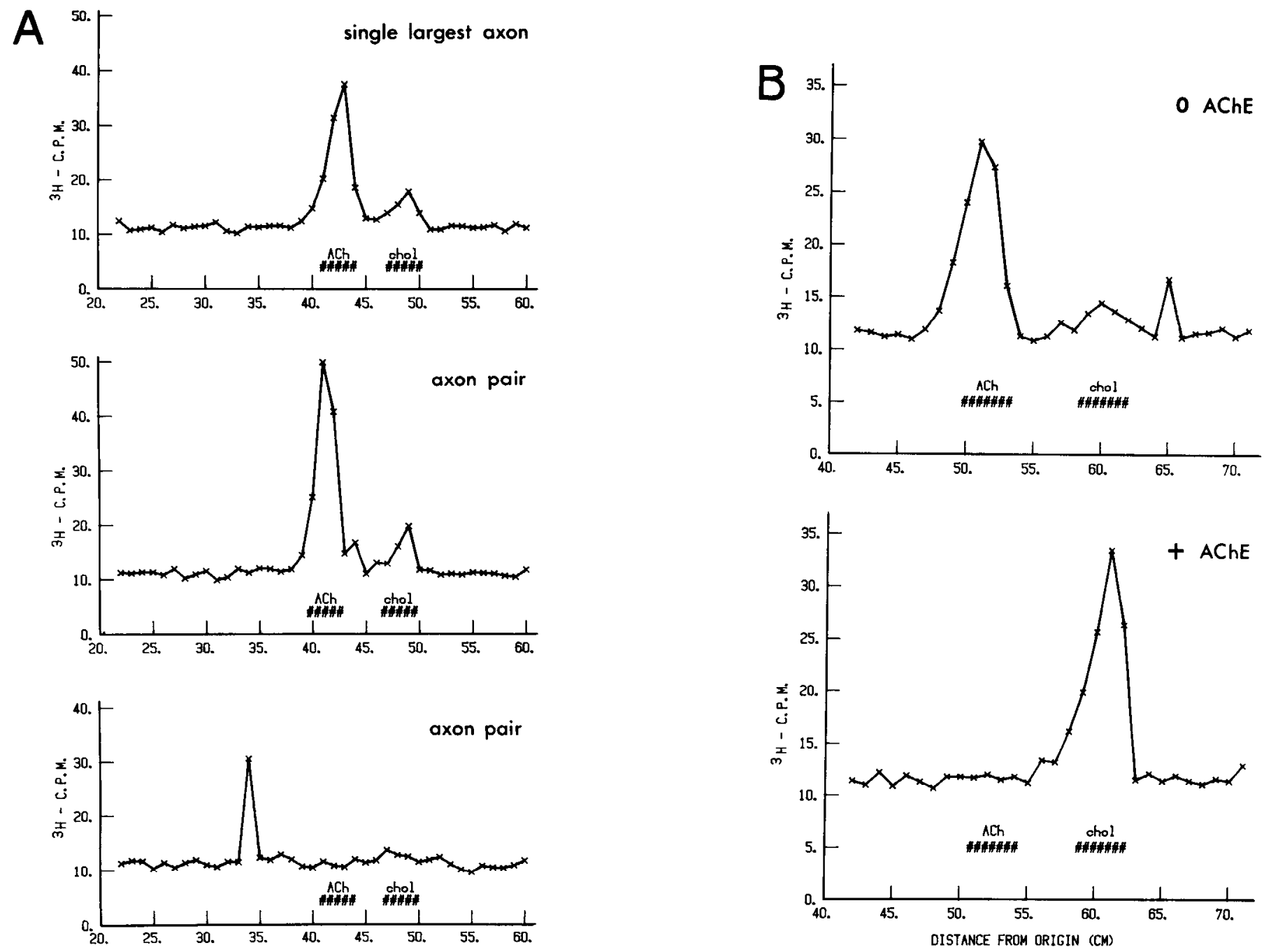

Figure 6. Electrophoretic profiles of radioactivity in aliquots of the extracts of axons dissected from the nerve that innervates the oval organ, incubated overnight with ${ }^{3} \mathrm{H}$-choline $(100 \mu \mathrm{Ci} / \mathrm{ml})$. The positions of $A C h$ and choline $(c h o l)$ were marked with cold standards. $A$, Five large axons from 1 oval organ preparation were separated into the single largest axon and 2 axon pairs. The largest axon and one of the pairs contained peaks of activity comigrating with $A C h$, while the other pair did not. $B$. Two aliquots of the extract of the largest axon from another oval organ preparation before (0) and after (+) AChE treatment. All radioactivity migrating with $A C h$ was converted to ${ }^{3} \mathrm{H}$-choline (chol) by the AChE treatment.

peptide purified by 2 sequential HPLC steps. The purified peptide had the same molecular weight as synthctic proctolin (Schwarz et al., 1984). In addition, several lobster tissue samples were analyzed with 2 different HPLC solvent systems, and tissue PLI comigrated with synthetic proctolin in both systems (e.g., Marder et al., 1986).

Given the likely presence of authentic proctolin in several classes of identified lobster neurons, investigations of the physiological roles of proctolin in the lobster can now be focused on these specific neurons. Moreover, by knowing the identities of the conventional neurotransmitters that coexist with proctolin, the actions of the peptide can be assessed in an appropriate context.

\section{Serotonin-proctolin cells in $T 5$ and AI}

Previous studies have provided evidence that both serotonin (Livingstone et al., 1980) and proctolin (Schwarz et al., 1984) may function as neurohormones in lobster. The present results, demonstrating the colocalization of these substances, suggest that they might be released together from endings of the $\mathrm{T} 5$ and Al cells and act as cohormones. Axonal projections of the T5 and A1 serotonin-proctolin cells arborize in peripheral neurosecretory regions as well as in the neuropil of central ganglia (see the following paper by Beltz and Kravitz, 1987). We are at present exploring possible functional interactions between the peptide and the amine in mediating the effects of these cells on the motor output of central ganglia.

\section{Dopamine-proctolin cells in the $C G$}

In all crustacean species where the transmitter identity of the large CG neuron has been examined, there is evidence that the cell is dopaminergic (Cooke and Goldstone, 1970; Barker et al., 1979; Kushner and Barker, 1983; Cournil et al., 1984). Our studies of the large neuron in the lobster CG show further that the cell contains proctolin. The presence of proctolin in this neuron, however, appears to be variable from species to species. The cell shows proctolin-like immunocytochemical staining in the lobster, Homarus americanus, and the crabs, Cancer irrora- 
tus and $C$. borealis, but does not stain for proctolin in the crayfish, Procambarus clarkii, or spiny lobster, Panulirus interruptus (Marder et al., 1986; Siwicki and Bishop, 1986). Thus, although the dopaminergic properties of this cell appear to be highly conserved among decapod crustaceans, its levels of proctolin may vary widely from species to species.

Like the T5 and Al serotonin-proctolin cells, the large CG neuron may be a source of hormonally released proctolin in lobsters. The axonal projection of the homologous neuron in the crab CG was traced with catecholamine fluorescence histochemistry to neurosecretory endings in the pericardial organs (Cooke and Goldstone, 1970). Thus, proctolin and DA might be released together and act as cohormones when this neuron is active. Physiological studies of the large CG neuron in Homarus gammarus indicated that its activity is correlated with the rhythmic output of the stomatogastric ganglion, suggesting that the cell is most active when the animal is feeding (Robertson and Moulins, 1981).

\section{ACh-proctolin sensory neurons}

The sensory neurons of the oval organ mechanoreceptor of the scaphognathite, like many lobster sensory neurons, take up exogenous choline and convert it to $\mathrm{ACh}$. They presumably release $\mathrm{ACh}$ from their central endings. The presence of proctolin in the sensory dendrites, and the morphological evidence for large, electron-dcnse granules (Pasztor, 1979), together with the tonic depolarizations of the sensory fibers in response to mechanical stretch of the oval organ (Pasztor and Bush, 1982), raise the possibility that proctolin might be released peripherally from the sensory dendrites. In mammals, the release of substance $\mathbf{P}$ from peripheral sensory endings appears to mediate local vasodilatation (Lembeck and Holzer, 1979). In a similar manner, proctolin released from the oval organ sensory dendrites might act on nearby targets. In preliminary experiments, Pasztor and coworkers have observed excitatory effects of proctolin on muscles close to the oval organ and inhibitory effects on the oval organ sensory neurons (Pasztor et al., 1985). This raises the possibility that proctolin may modulate the adaptation properties or the gain of sensory transduction mechanisms, which would be an exciting and novel action for the peptide.

\section{Proctolin in motoneurons}

In addition to these neurosecretory and sensory neurons, proctolin is also present in 1 of the 6 tonic flexor motoneurons in abdominal ganglia of the lobster (Siwicki et al., 1985). The classical, rapidly acting transmitter of these motoneurons has not been identified, although there is some evidence suggesting that it may be glutamate (Takeuchi and Takeuchi, 1964; Kravitz et al., 1970). Nonetheless, the slow contractures induced by proctolin in this muscle are distinctly different from the fast twitches and junctional potentials elicited by single action potentials in the motoneurons (E. A. Kravitz, unpublished observations), suggesting that proctolin coexists in tonic flexor motoneurons with the conventional fast-acting transmitter. In the crayfish abdomen, 3 of the 6 tonic flexor motoneurons contain proctolin (Bishop et al., 1984a), and physiological studies indicate that proctolin released by high-frequency stimulation enhances the amplitude of succeeding nerve-evoked contractions (Bishop et al., 1984b, 1985). In these and other proctolin-containing motoneurons (O'Shea and Bishop, 1982; Adams and O'Shea, 1983; Worden et al., 1985) the actions of the peptide as a cotransmitter are better established than is the identity of the conventional, fast-acting neuromuscular transmitter.

Among vertebrate and invertebrate neuropeptides, only proctolin has been localized to so many different identified neurons. Motoneurons, neurosecretory cells, and sensory neurons all contain the pentapeptide that was originally found in the cockroach hindgut (Brown and Starratt, 1975). From the accumulated results of 10 years of research on proctolin, it is clear that a peptide cannot be considered to have a single functional role in an organism, to be colocalized exclusively with a single classical transmitter, or to be expressed consistently in homologous neurons in related species. Whether the peptide has diverse effects in its various targets or a common mechanism of action that is applied in different contexts will be resolved by further studies of the functions of proctolin in these identified neurons.

\section{References}

Adams, M. E., and M. O'Shea (1983) Peptide co-transmitter at a neuromuscular junction. Science 221: 286-290.

Barker, D. L., E. Herbert, J. G. Hildebrand, and E. A. Kravitz (1972) Acetylcholine and lobster sensory neurones. J. Physiol. (Lond.) 226. 205-229.

Barker, D. L., P. D. Kushner, and N. K. Hooper (1979) Synthesis of dopamine and octopamine in the crustacean stomatogastric nervous system. Brain Res. 161: 99-113.

Beltz, B. S., and E. A. Kravitz (1983) Mapping of serotonin-like immunoreactivity in the lobster nervous system. J. Neurosci. 3: 585602.

Beltz, B. S., and E. A. Kravitz (1987) Physiological identification, morphological analysis, and development of identified serotoninproctolin containing neurons in the lobster ventral nerve cord. $J$. Neurosci. 7: 533-546.

Bishop, C. H., M. O'Shea, and R. J. Miller (1981) Neuropeptide proctolin (H-Arg-Tyr-Leu-Pro-Thr-OH): Immunological detection and neuronal localization in insect central nervous system. Proc. Natl. Acad. Sci. USA 78: 5899-5902.

Bishop, C. A., J. J. Wine, and M. O'Shea (1984a) Neuropeptide proctolin in postural motoneurons of the crayfish. J. Neurosci. 4: 20012009.

Bishop, C. A., F. Nagy, J. J. Wine, and M. O'Shea (1984b) Neural release and physiological action of an identified peptide contained in crayfish motor neurons. Soc. Neurosci. Abstr. 10(pt. 1): 151 .

Bishop, C. A., J. J. Wine, and M. O'Shea (1985) Neural release of a peptide co-transmitter greatly enhances tension generation in a crayfish tonic muscle. Soc. Neurosci. Abstr. 11(pt. 1): 327.

Brown, B. E., and A. N. Starratt (1975) Isolation of proctolin, a myotropic peptide, from Periplaneta americana. J. Insect Physiol. 21: 1879-1881.

Cooke, I. M., and M. Goldstone (1970) Fluorescence localization of monoamines in crab neurosecretory structures. J. Exp. Biol. 53: 651668.

Cournil, I., M. Geffard, M. Moulins, and M. LeMoat (1984) Coexistence of dopamine and serotonin in an identified neuron of the lobster nervous system. Brain Res. 310: 397-400.

Hildebrand, J. G., D. L. Barker, E. Herbert, and E. A. Kravitz (1971) Screening for neurotransmitters: A rapid radiochemical procedure. J. Neurobiol. 2: 231-246.

Kravitz, E. A., C. R. Slater, K. Takahashi, M. D. Bounds, and R. M. Grossfeld (1970) Excitatory transmission in invertebrates: Glutamate as a potential neuromuscular transmitter compound. In Excit atory Synaptic Mechanisms, P. Andersen and J. K. S. Jansen, eds., pp. 85-93, Universitets Forlaget, Oslo.

Kuhlman, J. R., C. Li, and R. L. Calabrese (1985a) FMRF-amidelike substances in the leech. I. Immunocytochemical localization. J. Neurosci. 5: 2301-2309.

Kuhlman, J. R., C. Li, and R. L. Calabrese (1985b) FMRF-amidelike substances in the leech. II. Bioactivity on the heartbeat system. J. Neurosci. 5: 2310-2317.

Kushner, P. D., and D. L. Barker (1983) A neurochemical description of the dopaminergic innervation of the stomatogastric ganglion of the spiny lobster. J. Neurobiol. 14: 17-28. 
Lembeck, F., and P. Holzer (1979) Substance P as neurogenic mediator of antidromic vasodilation and neurogenic plasma extravasation. Naunyn Schmiedebergs Arch. Pharmacol. 310: 175-183.

Livingstone, M. S., R. M. Harris-Warrick, and E. A. Kravitz (1980) Serotonin and octopamine produce opposite postures in lobsters. Science 208: 76-79.

Lloyd, P. E. (1982) Cardioactive neuropeptides in gastropods. Fed. Proc. 41: 2948-2952.

Lloyd, P. E., B. P. Masinovsky, R. E. McCaman, and A. O. D. Willows (1981) Coexistence of neuropeptide and acetylcholine in identified molluscan neuron. Soc. Neurosci. Abstr. 7: 637.

Lloyd, P. E., A. C. Mahon, I. Kupfermann, J. L. Cohen, R. H. Scheller, and K. R. Weiss (1985) Biochemical and immunocytological localization of molluscan small cardioactive peptides in the nervous system of Aplysia californica. J. Neurosci. 5: 1851-1861.

Lundberg, J. M. (1981) Evidence for coexistence of vasoactive intestinal polypeptide (VIP) and acetylcholine in neurons of cat exocrine glands. Acta Physiol. Scand. (Suppl. 496) 112: 1-57.

Lundberg, J. M., and T. Hökfelt (1983) Coexistence of peptides and classical neurotransmitters. Trends Neurosci. 6: 325-333.

Lundberg, J. M., J. Fahrenkrug, O. Larsson, and A. Angaard (1984) Corelease of vasoactive intestinal polypeptide and peptide histidine isoleucine in relation to atropine-resistant vasodilation in cat submandibular salivary gland. Neurosci. Lett. 52: 37-42.

Marder, E., S. L. Hooper, and K. K. Siwicki (1986) Modulatory action and distribution of the neuropeptide proctolin in the crustacean stomatogastric nervous system. J. Comp. Neurol. 243: 454-467.

Ono, J. K., and R. E. McCaman (1980) Identification of additional histaminergic neurons in Aplysia: Improvement of single cell isolation techniques for in tandem physiological and chemical studies. Neuroscience $5: 835-840$.

Ono, J. K., and R. E. McCaman (1984) Immunocytochemical localization and direct assays of serotonin-containing neurons in Aplysia. Neuroscience 11: 549-560.

Osborne, N. N. (1977) Do snail neurones contain more than one neurotransmitter? Nature 270: 622-623.

Osborne, N. N., A. C. Cuello, and G. J. Dockray (1982) Substance P and cholecystokinin-like peptides in Helix neurons and cholecystokinin and serotonin in a giant neuron. Science 216: 409-411.
O'Shea, M., and M. E. Adams (1981) Pentapeptide proctolin associated with an identified neuron. Science 213: 567-569.

O'Shea, M., and C. A. Bishop (1982) Neuropeptide proctolin associated with an identified skeletal motoneuron. J. Neurosci. 2: 12421251.

Pasztor, V.M. (1979) The ultrastructure of the oval organ, a mechanoreceptor in the second maxilla of decapod crustacea. Zoomorphologie 193: 171-191.

Pasztor, V. M., and B. M. H. Bush (1982) Impulse-coded and analog signaling in single mechanoreceptor neurons. Science 215: 1635-1637.

Pasztor, V. M., R. Katz, S. Weizner, and B. M. H. Bush (1985) Physiological actions of proctolin in the ventilatory system of crayfish and lobster. Soc. Neurosci. Abstr. 11(pt. 1): 711.

Robertson, R. M., and M. Moulins (1981) A corollary discharge of total foregut motor activity is monitored by a single interneurone in the lobster Homarus gammarus. J. Physiol. (Paris) 77: 823-827.

Schwarz, T. L., G. M.-H. Lee, K. K. Siwicki, D. G. Standaert, and E. A. Kravitz (1984) Proctolin in the lobster: The distribution, release and chemical characterization of a likely neurohormone. J. Neurosci. 4: $1300-1311$.

Siwicki, K. K., and C. A. Bishop (1986) Mapping of proctolin-like immunoreactivity in the nervous systems of lobster and crayfish. J. Comp. Neurol. 243: 435-453.

Siwicki, K. K., B. S. Beltz, T. L. Schwarz, and E. A. Kravitz (1985) Proctolin in the lobster nervous system. Peptides (Suppl. 3) 6: 393402.

Takeuchi, A., and N. Takeuchi (1964) The effect on crayfish muscle of iontophoretically applied glutamate. J. Physiol. (Lond.) 170: 296317.

Willows, A. O. D. (1985) Acetylcholine and peptide $\mathrm{SCP}_{\mathrm{b}}$ which cooccur in an identified buccal neuron B11 of Tritonia have opposite effects upon the feeding motor program. Soc. Neurosci. Abstr. 11 (pt. 1): 90 .

Worden, M. K., J. L. Witten, and M. O'Shea (1985) Proctolin is a cotransmitter for the SETi motoneuron. Soc. Neurosci. Abstr. 11 (pt. 1): 327. 